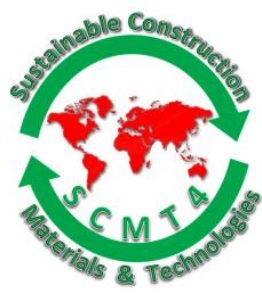

SCMT4

Las Vegas, USA, August 7-11, 2016

\title{
Mechanical Properties of Refractory Composites with Granulated Ceramic Fibers
}

\author{
Marcel Jogl $^{1 \mathrm{a}}$, Pavel Reiterman ${ }^{1 \mathrm{~b}}$, Ondř̌j Holčapek ${ }^{1 \mathrm{c}}$, and Petr Konvalinka ${ }^{1 \mathrm{~d}}$ \\ ${ }^{1}$ Experimental Centre; Czech Technical University in Prague, Thakurova 7, 16629, Prague, Czech \\ Republic. ${ }^{1 a}$ Email: <marcel.jogl@fsv.cvut.cz>, ${ }^{l b}$ Email: <pavel.reiterman@fsv.cvut.cz>, \\ ${ }^{1 c}$ Email: <ondrej.holcapek@fsv.cvut.cz>, ${ }^{1 d}$ Email: <petr.konvalinka@fsv.cvut.cz>.
}

\begin{abstract}
This paper deals with the experimental study of aluminous cement-based composites with applications of granulated ceramic fibers and different types of aggregates. The studied composites were developed for high temperature applications, thus the response to gradual temperature loading was carried out in the experimental program (up to $600{ }^{\circ} \mathrm{C}$ and $1000{ }^{\circ} \mathrm{C}$ ). An evaluation was performed in order to determine the final and residual values of the bulk density and mechanical properties - flexural and compressive strength. Used granulated ceramic fibers were applied in doses of $0.5 \%, 1.0 \%, 2.0 \%, 4.0 \%$ and $8.0 \%$ by volume. The influence of aggregate types was investigated for each dosage of fibers. Natural basalt, crushed fireclay, and expanded glass were selected as a fillers of constant volume for the mixtures. The results obtained confirmed the essential impact of fiber application, predominantly on the increase of flexural strength. However, flexural strength was not increased linearly with fiber dosage. An application dose of $8.0 \%$ of fibers by volume was not an efficient solution, because of only minimal improvement. Additionally, an extreme dosage of ceramic fibers reduced the values of bulk density and the proportional values of compressive strength for all studied combinations of aggregates. The optimal dosage seems to be $4.0 \%$ by volume. Bulk density was reduced after the temperature loading by $5 \%$, resp. $10 \%$ due to microstructural changes, but mixtures with ceramic fibers exhibited slightly better stability. Generally, the best resistance to high temperature was reached with mixtures with fireclay aggregate, as was expected. The application of expanded glass as a filler significantly contributed to the reduction of the bulk density on the level of lightweight composites, which is often required. It can be concluded that the application of granulated ceramic fibers essentially increased the subject properties, as well as the resistance to high temperature of developed composites.
\end{abstract}

\section{INTRODUCTION}

Refractory composites are materials developed for high temperature application to protect installed technologies, structures, and human life. They are usually made from high utility components. The development of fire barriers, which are based on aluminous cement, has become an integral part of the building industry, especially with regard to the current global political and security situation. Aluminous cement has excellent characteristics in relation to high temperatures in comparison to traditional Portland cement. One of the best-known techniques for producing refractory composites is by mixing selected components, and then casting them to obtain the required shape [Katsavou et al. 2012]. 
Concrete undergoes sequences of structural changes determined by actual thermal load level. The first phase is the evacuation of physicallybonded water taking place up to $200{ }^{\circ} \mathrm{C}$. Low permeability of high performance concrete (HPC) causes internal stresses incurred by accumulated steam. A sudden escape of steam is often the reason of surface spalling of High Performance Concrete (HPC). The behaviour of concrete surface layer of HPC, with special consideration to spalling, has been previously described [Černý et al. 2005; Fu and Li 2011].

After evacuation of the physically bonded water at $200^{\circ} \mathrm{C}$, and gradual decomposition of $\mathrm{CSH}$, there is a crucial temperature level at about $400^{\circ} \mathrm{C}$ when portlandite $\mathrm{Ca}(\mathrm{OH})_{2}$, an important hydration product, decomposes to quicklime and water [Keppert et al. 2012; Reiterman et al. 2015]. When a thermal load of $573^{\circ} \mathrm{C}$ is reached, crystal lattice transformation of quartz occurs, which is accompanied by extensive volume changes and crack formation. Increasing the thermal level causes a loss of integrity. The origin of the ceramic bond was observed, but the weak binding ability of this system cannot withstand successive hydration of quick lime. For this reason, Portland cement-based composites and concretes are not suitable for high temperature applications. An indispensable component is aluminous cement, which exhibits excellent resistance to high temperature [Jogl et al. 2016].

The residual properties of refractories are often ensured by applying a fiber reinforcement, which helps to resist tension stresses predominantly emerging from volume changes. Increasing the tensile strength of the final composite reduces crack initiation [Mirza and Soroushian 2002; Gao et al. 1997; Kavali et al. 2003; Libre et al. 2011]. The fibers can be made from natural materials, such as asbestos, sisal, basalt, and cellulose, or from manufactured products such as glass, steel, carbon, and polymers [Zanotti et al. 2014].

There is a significant role in the case of refractory composites containing asbestos fibers used in tile structures. The excellent properties of these fibers are unfortunately limited by their undesirable health consequences, which were noted after numerous performed reconstructions. However, the result of an extensive use of asbestos-containing products involved the exposure of numerous workers in diverse occupations to asbestos, and the resulting development of asbestos-related diseases after a certain period of latency [10]. The evident relationship between asbestos exposure and the risk of cancer has been presented in several research works [Hatina 2012; Holčapek et al. 2015; Lacourt et al. 2014].

It is necessary to find new alternative reinforcing material with satisfactory properties [Artemenko 2000; Greybeal 2007; Vejmelková and Černý 2013] and required resistance to fire or aggressive environments. Due to economic aspects, basalt and ceramic fibers, which have suitable primary resistance, are often applied. Ceramic fibers have been chosen for this research work, together with the various aggregates and aluminous.

\section{EXPERIMENTAL INVESTIGATION}

The experimental program investigated the composition of refractory fiber-reinforced composites and their response to gradual thermal loading. The evaluation was based on determining their basic physical and mechanical properties. The composite was composed of three types of aggregates - basalt (BA series), and combination of expanded glass and chamotte (LW series). The subject composites were reinforced with different amount of ceramic fibers $(0.5 \%, 1.0 \%, 2.0 \%, 4.0 \%$ and $8.0 \%)$ by mass which reflects the designation of particular mixtures. The application of an efficient plasticizer is necessary to preserve good workability and a low rate of water-cement ratio. Polycarboxylate plasticizer was used in a dose of $2.5 \%$ of binder based on previous research. Negative impacts of the subject organic compound, including its flammability were not confirmed [Jogl et al. 2014]. Aluminous cement Secar 71 was used as a binder to reach sufficient thermal resistance. 


\section{Materials}

Aluminous cement. The refractory composites were based on aluminous cement in order to achieve the required high temperature resistance, which is determined by the content of $\mathrm{Al}_{2} \mathrm{O}_{3}$ [Cardoso et al. 2004]. Secar71 aluminous cement containing $\geq 71 \%$ of $\mathrm{Al}_{2} \mathrm{O}_{3}$ ) was used in our experimental program. The chemical composition and the specific surface area measured by Blaine apparatus are shown in Table 1. This composition enables the cement to be applied at up to $1700^{\circ} \mathrm{C}$.

\section{Table 1. Chemical Composition of Used Cement}

\begin{tabular}{|c|c|c|c|c|c|c|c|c|}
\hline & $\begin{array}{c}\mathrm{Al}_{2} \mathrm{O}_{3} \\
(\%)\end{array}$ & $\begin{array}{c}\mathrm{CaO} \\
(\%)\end{array}$ & $\begin{array}{c}\mathrm{SiO}_{2} \\
(\%)\end{array}$ & $\begin{array}{c}\mathrm{Fe}_{2} \mathrm{O}_{3} \\
(\%)\end{array}$ & $\begin{array}{c}\mathrm{MgO} \\
(\%)\end{array}$ & $\begin{array}{c}\mathrm{TiO}_{2} \\
(\%)\end{array}$ & $\begin{array}{c}\mathrm{LOI} \\
(\%)\end{array}$ & $\begin{array}{c}\text { Blaine } \\
\left(\mathrm{m}^{2} / \mathrm{kg}\right)\end{array}$ \\
\hline Cement & 70.80 & 27.50 & 0.58 & 0.42 & 0.21 & 0.37 & 0.49 & 381 \\
\hline
\end{tabular}

Basalt aggregate. Fine, crushed basalt aggregates of two fractions, 0-4 $\mathrm{mm}$ and 2-5 $\mathrm{mm}$, were designed into the composite composition. The application of natural aggregates significantly contributed to the economic aspects of composite materials. Particle size distribution of the used basalt aggregates was investigated by using the EU standard system of sieves. The current design of fine grain composites makes possible varied doses of fibers, including relatively high doses. Particle size distribution of used basalt aggregates is shown in Figure 1.

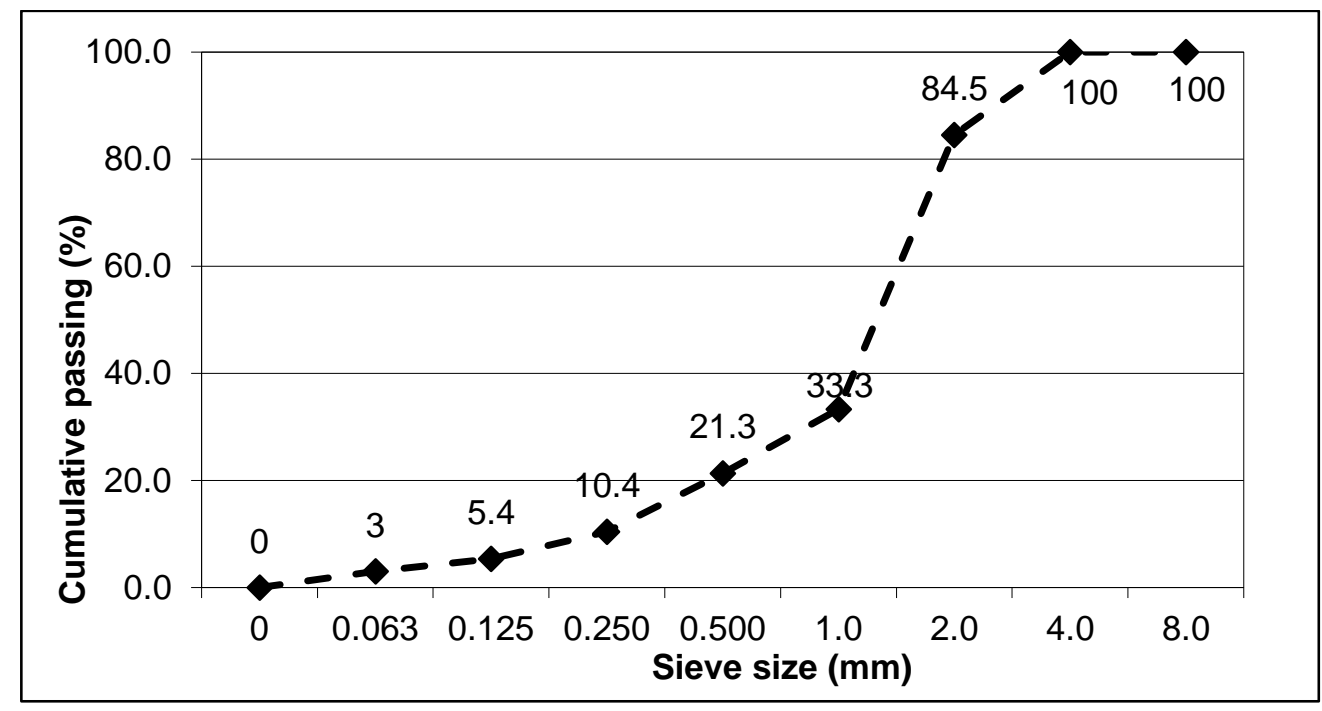

Figure 1. Particle Size Distribution of Used Basalt Aggregate

Ceramic aggregate. Ceramic aggregate in the form of chamotte fireclay was used as a filler. Fireclay aggregates are commercially-produced artificial materials used for producing temperature-resistant elements. The amount of aluminous oxides (a minimum of 40) has an essential influence on the aggregates that are used. The amount of $\mathrm{Fe}_{2} \mathrm{O}_{3}$, which has a negative effect on the temperature resistance, is limited to $4 \%$. The minimal amount of $\mathrm{SiO}_{2}$ is just about $30 \%$ by weight. The fireclay is crushed and is distributed in the required grading. A suitable composition of ceramic aggregates ensures that it can be applied at over $1700^{\circ} \mathrm{C}$, which is of great interest in the metallurgical and chemical industries. The refractory quality of high-alumina materials is usually higher than that of fireclay-bearing refractories. Nevertheless, fireclay refractories are still the most widely used type, due to their ease of fabrication, resistance to chemical attack, and relatively low cost [Andrews et al. 2013; Jogl et al. 2016]. 
Liaver. Liaver is expanded glass granulate with a closed surface, which is produced from recycled glass applying a patented technique. This granulate is sintered at a temperature of 750 to $900{ }^{\circ} \mathrm{C}$ in a rotary kiln. Liaver is dry, light, non-toxic, free of dangerous substances, non-flammable (classification of fire A1), and highly resistant to pressure (Liaver). The final product is in the form of closed balls of requisite grading. A detailed chemical composition is shown in Table 2.

Ceramic fibers. Very short ceramic fibers (length of $0.2 \mathrm{~mm}$ and diameter of $0.01 \mathrm{~mm}$ ) were used for the development of new types of refractory composites. Used ceramic fibers allow their practical utilization for high-temperature application, just up to $1500^{\circ} \mathrm{C}$. A detailed chemical composition of used ceramic fibers is shown in Table 3.

Table 2. Chemical Composition of Liaver

\begin{tabular}{|c|c|c|c|c|c|c|c|}
\hline & $\begin{array}{c}\mathrm{Al}_{2} \mathrm{O}_{3} \\
(\%)\end{array}$ & $\begin{array}{c}\mathrm{CaO} \\
(\%)\end{array}$ & $\begin{array}{c}\mathrm{SiO}_{2} \\
(\%)\end{array}$ & $\begin{array}{c}\mathrm{Fe}_{2} \mathrm{O}_{3} \\
(\%)\end{array}$ & $\begin{array}{c}\mathrm{Na}_{2} \mathrm{O} \\
(\%)\end{array}$ & $\begin{array}{c}\mathrm{MgO} \\
(\%)\end{array}$ & $\begin{array}{c}\mathrm{K}_{2} \mathrm{O} \\
(\%)\end{array}$ \\
\hline Liaver & 2.3 & 10.0 & 71.0 & 0.7 & 4.0 & 3.0 & 1.2 \\
\hline
\end{tabular}

Table 3. Chemical Composition of Used Ceramic Fibers

\begin{tabular}{|c|c|c|c|c|c|c|c|c|c|}
\hline & $\begin{array}{c}\mathrm{Al}_{2} \mathrm{O}_{3} \\
(\%)\end{array}$ & $\begin{array}{c}\mathrm{CaO} \\
(\%)\end{array}$ & $\begin{array}{c}\mathrm{SiO}_{2} \\
(\%)\end{array}$ & $\begin{array}{c}\mathrm{Fe}_{2} \mathrm{O}_{3} \\
(\%)\end{array}$ & $\begin{array}{c}\mathrm{Na} 2 \\
(\%)\end{array}$ & $\begin{array}{c}\mathrm{MgO} \\
(\%)\end{array}$ & $\begin{array}{c}\mathrm{K}_{2} \mathrm{O} \\
(\%)\end{array}$ & $\begin{array}{c}\mathrm{ZrO}_{2} \\
(\%)\end{array}$ & $\begin{array}{c}\mathrm{TiO}_{2} \\
(\%)\end{array}$ \\
\hline fibers & 44.0 & 0.22 & 53.7 & 0.66 & 0.05 & 0.38 & 0.2 & 0.57 & 0.60 \\
\hline
\end{tabular}

\section{Methods}

Temperature loading. Gradual temperature loading was performed in the automatic electric furnace at a heating rate $10{ }^{\circ} \mathrm{C} / \mathrm{min}$. After reaching the required level $\left(600{ }^{\circ} \mathrm{C}\right.$ or $\left.1000{ }^{\circ} \mathrm{C}\right)$, samples were spontaneously cooled down after three hours. . Reference specimens to thermal loaded samples were dried at $105{ }^{\circ} \mathrm{C}$ for 24 hours (to evaporate free water from their inner pore structure) before testing.

Physical and mechanical properties. The bulk density $\left(\mathrm{kg} / \mathrm{m}^{3}\right)$ of the studied composites was investigated on the base of the actual weight and accurate dimensions of specimens. All tests of mechanical properties were carried out on prismatic specimens of $40 \times 40 \times 160 \mathrm{~mm}^{3}$. Flexural strength $f_{t m}$ (MPa) measurement was organized as a three-point test with a support distance of $100 \mathrm{~mm}$, and was calculated by help of the maximum reached force. The compressive strength $f_{c m}$ (MPa) test was performed on two fragments left after the flexural test. The area under the compressive load $\left(40 \times 40 \mathrm{~mm}^{2}\right)$ was demarcated by the loading device.

Mixture proportions. As in the case of other types of special composites, the mixing procedure of studied refractory composites has a prescribed procedure with a strictly prescribed sequence. The mixing process in the laboratory horizontal mixer consisted of three periods: The first involved a three-minute period of homogenization of cement with aggregates and fibers; the second period started with the dosing of $80 \%$ of water together with plasticizer and continual mixing for another 3 minutes.; and the third period involved consisted of mixing the addition of a full dose of water and mixing for one minute. Only 
the strictest compliance of this procedure could ensure the homogeneity of the final composite. Aggregate content was set as constant to 0.38 of mass. Detailed composition is shown in Table 4.

Table 4. Composition of Studied Mixtures $\left(\mathrm{kg} / \mathrm{m}^{3}\right)$

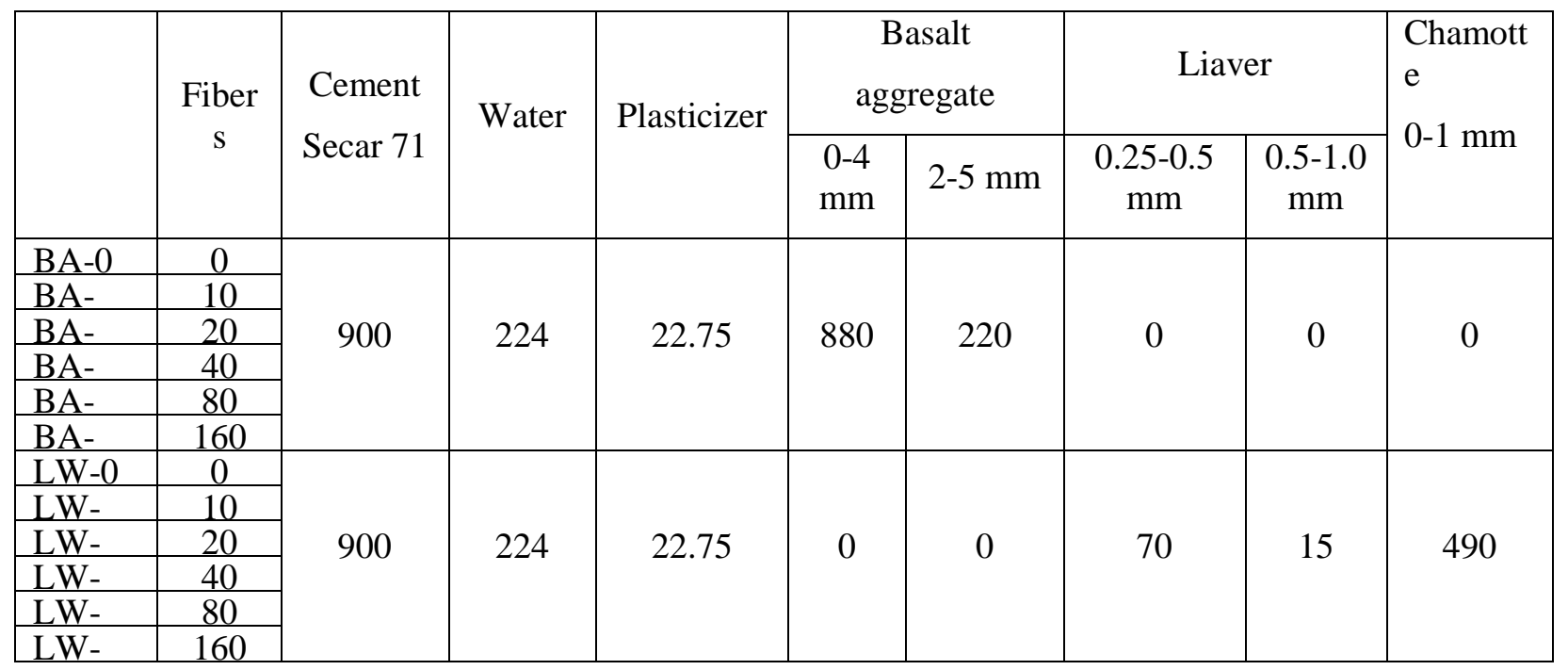

\section{RESULTS AND DISCUSSIONS}

The following table presents the results of measurements of the flexural strength, compressive strength, and bulk density of all examined mixtures. All the values of the studied properties, which are presented after drying at $105^{\circ} \mathrm{C}$ (reference set) and after exposure to $600^{\circ} \mathrm{C}$ and $1000^{\circ} \mathrm{C}$, are shown in Table 5. The values presented in Table 3 are the results of three samples (with the exception of the compressive strength, which is the average of the results of six tests).

Table 5. Detailed Results of Measurement

\begin{tabular}{|l|c|c|c|c|c|c|c|c|c|}
\hline & \multicolumn{3}{|c|}{ Compressive strength (MPa) } & \multicolumn{2}{c|}{ Flexural strength $(\mathrm{MPa})$} & \multicolumn{3}{c|}{ Bulk density $\left(\mathrm{kg} / \mathrm{m}^{3}\right)$} \\
\cline { 2 - 11 } & $105^{\circ} \mathrm{C}$ & $600^{\circ} \mathrm{C}$ & $1000^{\circ} \mathrm{C}$ & $105^{\circ} \mathrm{C}$ & $600^{\circ} \mathrm{C}$ & $1000^{\circ} \mathrm{C}$ & $105^{\circ} \mathrm{C}$ & $600^{\circ} \mathrm{C}$ & $1000^{\circ} \mathrm{C}$ \\
\hline BA-0 & 47.7 & 31.1 & 18.8 & 5.2 & 2.1 & 1.5 & 2330 & 2260 & 2185 \\
\hline BA-0.5 & 65.3 & 58.6 & 19.9 & 7.8 & 4.7 & 2.1 & 2335 & 2276 & 2148 \\
\hline BA-1.0 & 71.3 & 61.5 & 19.5 & 8.8 & 4.4 & 2.0 & 2340 & 2283 & 2178 \\
\hline BA-2.0 & 82.5 & 60.2 & 19.8 & 8.8 & 4.5 & 1.9 & 2350 & 2291 & 2185 \\
\hline BA-4.0 & 78.1 & 57.3 & 20.9 & 8.2 & 3.1 & 2.0 & 2350 & 2220 & 2215 \\
\hline BA-8.0 & 47.5 & 30.6 & 17.9 & 8.4 & 3.7 & 2.1 & 2295 & 2240 & 2170 \\
\hline LW-0 & 88.1 & 91.8 & 54.5 & 12.5 & 8.1 & 7.9 & 1965 & 1763 & 1714 \\
\hline LW-0.5 & 99.1 & 78.4 & 52.8 & 11.5 & 7.7 & 9.0 & 1962 & 1724 & 1704 \\
\hline LW-1.0 & 92.3 & 74.6 & 50.7 & 11.6 & 7.8 & 9.3 & 1945 & 1695 & 1681 \\
\hline LW-2.0 & 70.5 & 69.1 & 49.1 & 12.4 & 8.3 & 9.4 & 1862 & 1641 & 1626 \\
\hline LW-4.0 & 65.2 & 59.4 & 48.2 & 10.5 & 8.0 & 8.6 & 1831 & 1609 & 1600 \\
\hline LW-8.0 & 53.2 & 48.6 & 38.6 & 8.3 & 6.9 & 7.3 & 1773 & 1595 & 1564 \\
\hline
\end{tabular}


The final values of compressive strength corresponds well with flexural strength results. The application of ceramic fibers increased the total values of compressive strength, but higher doses of ceramic fiber led to a reduction in this parameter, and seems to not be effective, see figure 2 . The application of ceramic fibers contributed to increased compressive strength for mixtures with basalt aggregate utilization up to a dose of $2.0 \%$ by volume. The effect of fibers due to thermal loading significantly reduced the final residual values reached very similar levels for all applied doses of ceramic fibers.

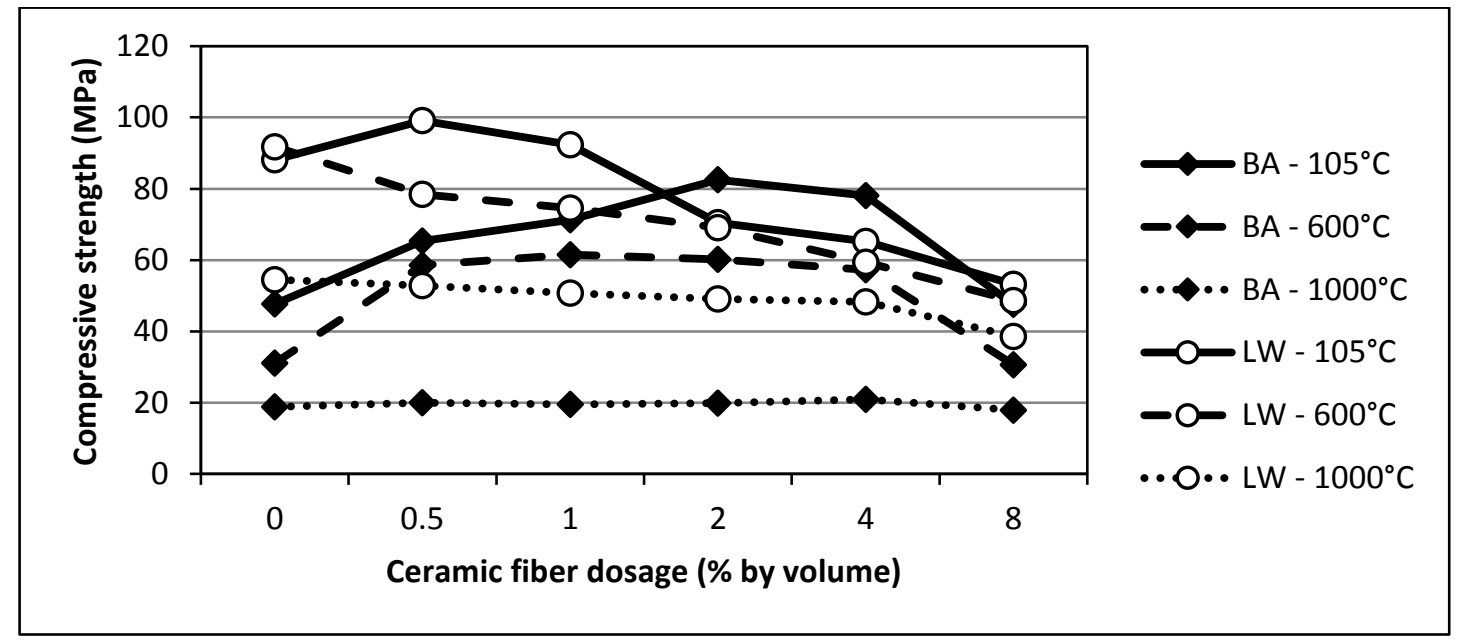

Figure 2. Dependence of Compressive Strength on the Dosage of Ceramic Fibers

Flexural strength was affected by the ceramic fibers application in various way for both studied types of composites, which is well illustrated in figure 3. An increased amount of used fibers led to a slight increase of flexural strength, predominantly after thermal loading. There are significant differences in the effects of ceramic fibers application for both types of studied composites. The obtained results clearly demonstrate the positive impact on the flexural strength in case of mixtures with basalt aggregate. Conversely, lightweight composites were negatively affected by the ceramic fiber applications in terms of the resulting flexural strength values of reference samples. However, it is obvious that fibers contributed to the thermal resistance of lightweight composites because of the increase in flexural strength of thermally loaded samples.

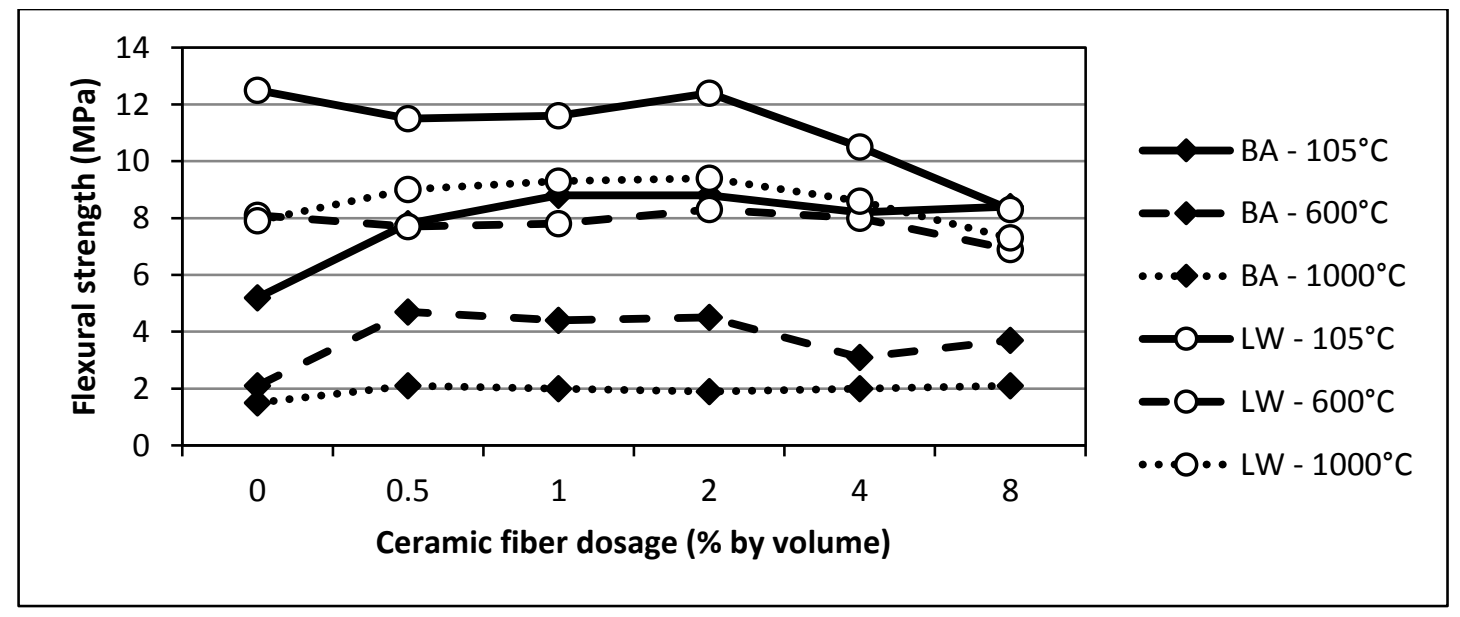

Figure 3. Dependence of Flexural Strength on the Dosage of Ceramic Fibers 
We can observe the gradual decay of bulk density due to effect of high temperature, when physically bounded water is evaporated first, Fig 4. An increase in temperature leads to a further decrease of bulk density, which is caused by partial chemical decomposition of hydration products. However, composite mixtures with basalt aggregate exhibited a decreased loss of bulk density in comparison with the lightweight mixtures. It is probably caused by the decomposition of Liaver aggregate.

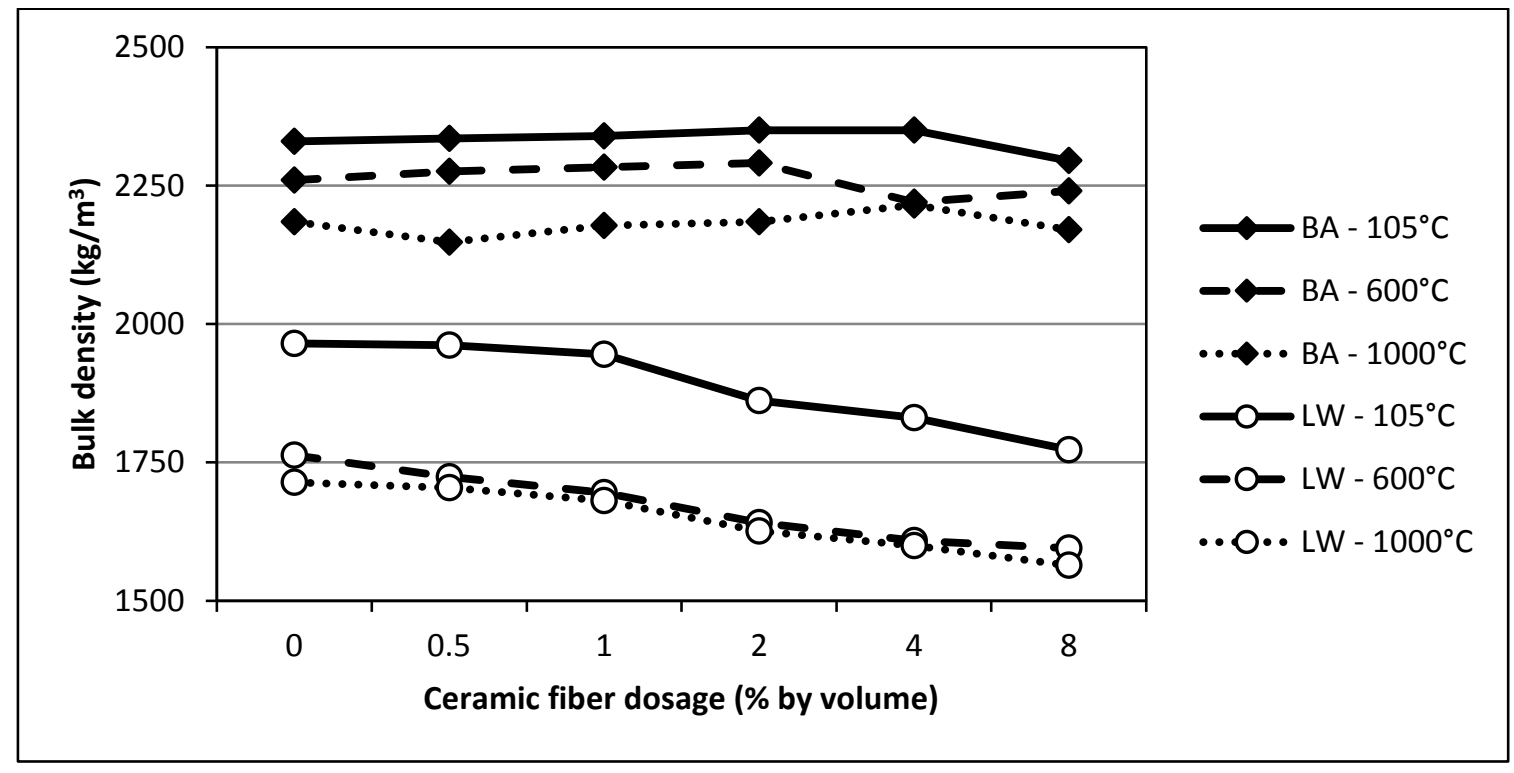

Figure 4. Dependence of Bulk Density on the Dosage of Ceramic Fibers

\section{CONCLUSION}

The following general conclusions can be drawn from the experimental study provided in the paper:

- Ceramic fibers contributed to the compressive strength values up to doses of 2.0 for mixtures of normal bulk density; lightweight composites were negatively affected by the ceramic fibers application; however, their positive effect was significant after thermal loading.

- Ceramic fibers influenced on the resistance of studied composites to thermal loading; high doses of ceramic fibers reduced the loss of all studied physical and mechanical properties.

- The obtained values of samples loaded up to $600^{\circ} \mathrm{C}$ corresponded well with reference samples which were not thermally loaded; residual values after $1000^{\circ} \mathrm{C}$ loading were similar for all applied fiber doses.

- Mixtures with the chamotte and Liaver aggregate exhibited increased stability and resistance to high temperature in comparison with natural basalt aggregate.

- Extreme doses of ceramic fibers could be used for the reduction of the bulk density of refractory composites while maintaining suitable mechanical properties.

\section{ACKNOWLEDGEMENTS}

This experimental work was generously supported by the Czech Science Foundation over project No. 104/12/0791. 


\section{REFERENCES}

Andrews, A., Adam, J., and Gawu, S. K. Y. (2013). "Development of Fireclay Aluminosilicate Refractory from Lithomargic Clay Deposits." Ceramics International, 39(1) 779-783.

Artemenko, S. W. (2000). "Polymer Composite Materials Made from Carbon, Basalt and Glass Fibers, Structure and properties." Fibre chemistry, 35, 226-229.

Cardoso, F. A., Innocentini, M. D. M, Akiyoshi, M. M., and Pandolfelli, V. C. (2004). "Effect of Curing Time on the Properties of CAC Bonded Refractory Castables." Journal of the European Ceramic Society, 24(7), 2073-2078.

Černý, R., Poděbradská, J., Toman, J., Jiříčková, M., Mňahončáková, E., Rovnaníková, P., and Bayer, P. (2005). "High Temperature Properties of Fibre Reinforced Cement Composites," Proceedings of the International Conference on Application of Codes, Design and Regulations, 2005, 403-412.

Fu, Y., and Li, L. (2011). "Study on Mechanism of Thermal Spalling in Concrete Exposed to Elevated Temperatures." Materials and structures, 44(1), 361-376.

Gao, J., Sun, W., and Morino, K. (1997). "Mechanical Properties of Steel Fiber-reinforced, High-strength, Lightweight Concrete." Cement and Concrete Composites, 19(4), 307-313.

Graybeal, B. A. (2007). "Compressive Behavior of Ultra-high-performance Fiber-reinforced Concrete." ACI Mater. J., 104, 146.

Hatina, J. (2012). “The Dynamics of Cancer Stem Cells.” Neoplasma, 59, 700-707.

Holčapek, O., Reiterman, P., and Konvalinka, P. (2015). "Fracture Characteristics of Refractory Composites Containing Metakaolin and Ceramic Fibers." Advances in Mechanical Engineering, 7(3), $1-13$.

Jogl, M., Reiterman, P., Holčapek, O., and J. Kot’átková. (2014). "Influence of High-temperature on Polycarboxylate Superplasticizer in Aluminous Cement Based Fibre Composites." Advanced Materials Research, 982, 125-129.

Jogl, M., Reiterman, P., Holčapek, O., Kot'átková, J., Konvalinka, P. (2016). "Residual Properties of Fiber-reinforced Refractory Composites with a Fireclay Filler." Acta Polytechnica, in press.

Katsavou, I. D., Krokida, M. K., and Ziomas, I. C. (2012). "Determination of Mechanical Properties and Thermal Treatment Behaviour of Alumina-based Refractories." Ceramics International, 38, 57475756.

Kavali, O., Haque, M. N., and Zhu, B. (2003). "Some Characteristics of High Strength Fiber Reinforced Lightweight Aggregate Concrete." Cement and Concrete Composites, 25(2), 207-213.

Keppert, M., Vejmelková, E., Švarcová, S., Bezdička, P., Černý, R. (2012). "Microstructural Changes and Residual Properties of Fiber Reinforced Cement Composites Exposed to Elevated Temperatures." Cement Wapno Beton, 17(2), 77-89.

Lacourt, A, Rinaldo, M., Gramond, C., Ducamp, S., Soil Ilg, A.l, G., Goldberg, M., Piron, J., C., and Brochard, P. (2014). "Co-expsure to Refractory Ceramic Fibers and Asbestos and Risk of Pleural Mesothelioma." European Respiratory Journal, 44, 725-733.

Libre, N. A., Shekarchi, M., Mahoutian, M., and Soroushian, P. (2011). "Mechanical Properties of Hybrid Fiber Reinforced Lightweight Aggregate Concrete Made with Natural Pumice." Construction and Building Materials, 25(5), 2458-2464. 
Mirza, F. A., and Soroushian, P. (2002). "Effects of Alkali-resistant Glass Fiber Reinforcement on Crack and Temperature Resistance of Lightweight Concrete." Cement and Concrete Composites, 24(2), 223227.

Reiterman, P., Holčapek, O., Jogl, M., and Konvalinka, P. (2015). "Physical and Mechanical Properties of Composites Made with Aluminous Cement and Basalt Fibers Developed for High Temperature Application." Advances in Materials Science and Engineering, 2015, 1-10.

Vejmelková, E., and Černý, R. (2013). “Thermal Properties of PVA-Fiber Reinforced Cement Composites at High Temperatures." Applied Mechanics and Materials, 377, 45-49.

Zanotti, C., Banthia, N, and Plizzari, G. (2014). "A Study of Some Factors Affecting Bond in Cementitious Fiber Reinforced Repairs." Cement and Concrete Research, 63, 117-126. 